\title{
PENEGAKAN HUKUM LINGKUNGAN BIDANG USAHA PERTAMBANGAN BATU BARA DI PROVINSI JAMBI
}

\section{DISERTASI}

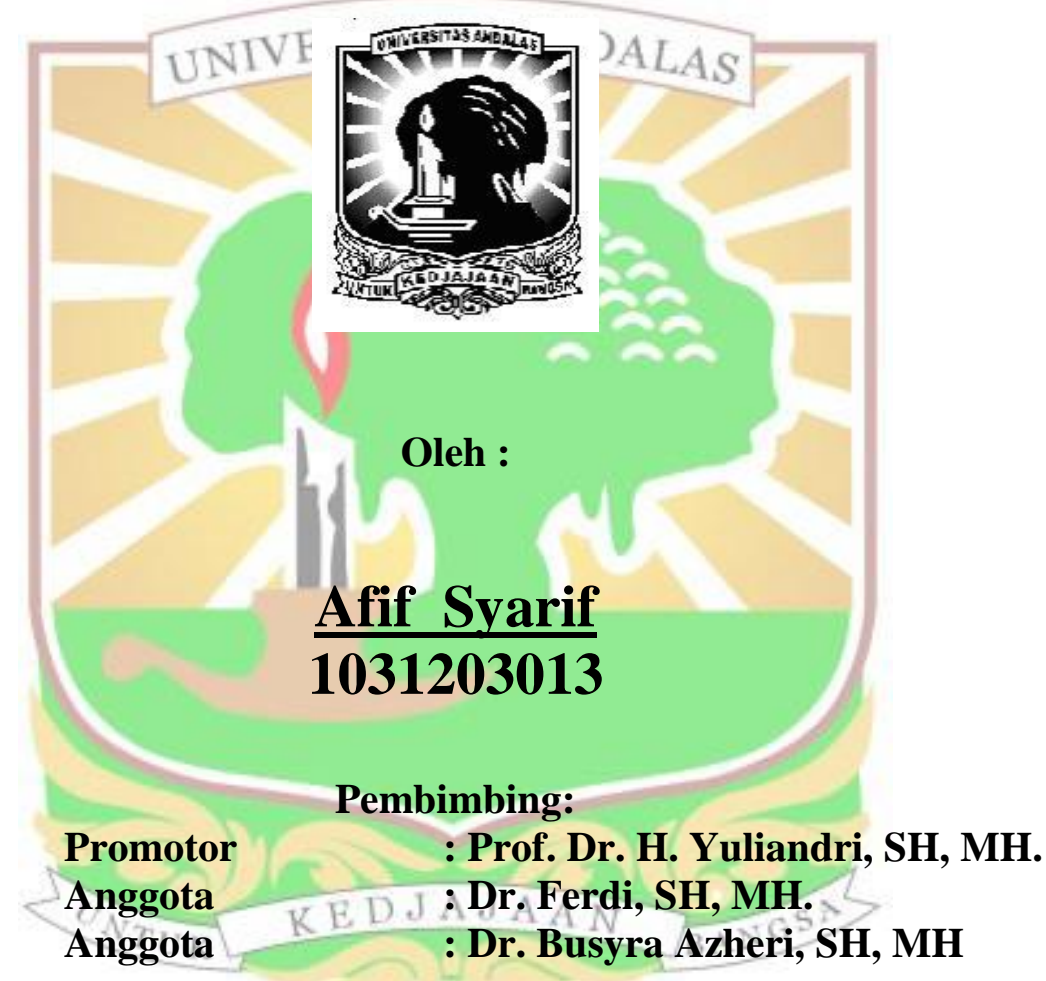

\section{PROGRAM DOKTOR ILMU HUKUM PASCASARJANA FAKULTAS HUKUM UNIVERSITAS ANDALAS PADANG, 2017}




\title{
PENEGAKAN HUKUM LINGKUNGAN BIDANG USAHA PERTAMBANGAN BATU BARA DI PROVINSI JAMBI
}

\author{
ABSTRAK \\ Afif Syarif \\ BP.1031203013
}

Penegakan hukum lingkungan terhadap usaha tambang batubara sebagai sumber daya alam tak terbarukan mempunyai peranan penting dalam memenuhi hajat hidup orang banyakk, Sserta memberi nilai tambah secara nyata bagi perekonomian nasional untuk mencapai kemakmuran dan kesejahteraan rakyat. Di Provinsi Jambi kegiatan usaha pertambangan batubara memiliki nilai ekonomis yang sangat tinggi, sehingga tidak tertutup kemungkinan terjadinya kerusakan lingkungan akibat eksploitasi dan eksploirasi terhadap tambang batubara tersebut. Tujuan penelitian ini adalah untuk menemukan dan menjelaskan konsep penegakan hukum lingkungan bidang pertambangan batubara dapat dilakukan melalui penguatan kelembagaan masyarakat adat. Metode yang digunakan untuk menjawab tujuan penelitian ini adalah menggunakan pendekatan yuridis normatif dan yuridis empiris dalam upaya menemukan konsep penegakan hukum lingkungan bidang usaha pertambangan batubara dengan mengkaji asas-asas hukum pertambangan dan hukum lingkungan dalam perspektif sumber kekayaan alam untuk kesejahteraan rakyat. Hasil penelitian menunjukan : Pertama pengaturan penegakan hukum lingkungan bidang usaha tambang batubara dapat diwujudkan melalui sistem IUP/WIUP batubara. Hal ini merupakan hakekat hukum lingkungan untuk mencegah terjadinya pencemaran dan kerusakan lingkungan. Kedua, konsep keadilan bidang usaha pertambangan batubara merupakan makna dan tujuan dalam penegakan hukum lingkungan. Untuk itu pemerintah daerah perlu mengeluarkan regulasi dalam kerangka penegakan hukum lingkungan bidang usaha pertambang batubara di Provinsi Jambi. Ketiga, penegakan hukum lingkungan bidang usaha pertambangan batubara di Provinsi Jambi dapat dilakukan melalui penguatan kelembagaan masyarakat adat berdasarkan Perda Nomor 5 Tahun 2007 tentang Lembaga Adat Melayu, dimana salah satu tugas dan fungsinya adalah, menginventarisir, mengamankan, memelihara dan mengurus serta memanfaatkan sumber kekayaan alam termasuk batubara untuk meningkatkan kesejahteraan rakyat di Provinsi Jambi.

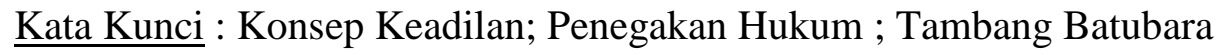




\title{
ENVIRONMENTAL LAW ENFORCEMENT OF COAL MINING BUSINESS IN JAMBI PROVINCE
}

\author{
ABSTRACT \\ Afif Syarif \\ BP.1031203013
}

Environmental law enforcement regarding coal mining business as nonrenewable natural resources hassimportant role in providing livelihood for many peoply, and grant the obvious value-added for national economy to attain people' prosperity and welfare. In Jambi Province, coal mining business has very high economic value, thus there is a possibility environmental damage will occur as the effect of exploitation and exploration toward the coal mine. The purpose of this research is to know and define the concept of environmental law enforcement of coal mining business could be done by the strengthening institutional of indigenous people. The method that applied for attaining the research purpose is normative and empiric juridical approach in attempt of finding the concept of environmental law enforcement in coal mining business by examine principles of mining law and environmental law with natural resources are for people welfare as the perspective. Results of the research indicate: First, the regulation of environmental law enforcement in coal mining business could be formed by coal mining license/ coal mining permit areas (IUP/WIUP) system. This is a nature of environmental law to prevent the environmental pollution and damage. Second, the concept of the justice of coal mining business as the meaning and purpose in environmental law enforcement. Therefore, local government needs to legislate regulations in framework of environmental law enforcement of coal mining business in Jambi Province. Third, environmental law enforcement of coal mining business in Jambi Province could be done by strengthening institutional of indigenous people based on Perda No.5/2007 regarding Malayu Adat Institution, where one of the duty and function are inventory, secure, preserve, take care of, also utilize the natural resources including coal to improve the welfare of people in Jambi Province.

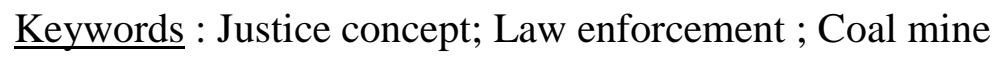

